\title{
Effects of high dietary crude protein on the characteristics of preovulatory follicles in dairy heifers
}

\author{
U. Moallem, ${ }^{* 1}$ R. Blanck, $\dagger$ H. Lehrer, ${ }^{*}$ L. Livshitz, ${ }^{*}$ M. Zachut, ${ }^{\star} \dagger$ and A. Arieli† \\ *Department of Dairy Cattle, Institute of Animal Sciences, Volcani Center, P.O. Box 6, Bet-Dagan, 50250 Israel \\ †Department of Animal Science, the Robert H. Smith Faculty of Agriculture, Food and Environmental Quality Sciences, \\ the Hebrew University of Jerusalem, Rehovot 76100 , Israel
}

\section{ABSTRACT}

The objectives were to examine the effect of high dietary crude protein on characteristics of preovulatory follicles in dairy heifers. Eight Israeli-Holstein heifers, 4 fitted with rumen fistula and 4 intact, were assigned to 1 of 3 treatments in a replicated $(\mathrm{n}=2) 4 \times 3$ incomplete Latin square design with 39 -d periods. Treatments were: low $(6.0 \%$; LP), moderate $(13.0 \%$; MP), and high $(20.0 \%$; HP) crude-protein diets, containing $1.27 \mathrm{Mcal} \mathrm{NE}_{\mathrm{L}} / \mathrm{kg}$ dry matter. Diets were based on approximately $66 \%$ wheat straw and various proportions of ground corn grain and soybean meal. The estrous cycles of the heifers were synchronized, and $14 \mathrm{~d}$ after behavioral estrus, heifers received $\mathrm{PGF}_{2 \alpha}$ injections. After a further $40 \mathrm{~h}$, at d 39 of each period, follicular fluid (FF) was aspirated from follicles of diameter $>7$ $\mathrm{mm}$. The intake of the LP diet was $9 \%$ lower than that of MP and HP diets. Rumen ammonia and plasma urea nitrogen concentrations were highest in the HP and lowest in the LP, with intermediate levels in MP diets. No differences were found between treatments in plasma and FF concentrations of glucose and nonesterified fatty acids. High-protein diets increased urea concentrations very similarly in preovulatory $\mathrm{FF}$ and in plasma. No differences were observed between diets, in preovulatory follicle diameters and concentrations of androstenedione. However, higher estradiol and progesterone concentrations in FF were observed under the HP than under the MP diet, with no difference between diets in estrogen to progesterone ratio. It can be concluded that high concentrations of urea in plasma, caused by high dietary crude protein, penetrated into preovulatory follicles, but did not impair preovulatory characteristics. This lack of detrimental effects might be attributed to the use in this study of nonlactating heifers, which have fewer nutritional and physiological constraints and eliminate negative effects of potential

Received June 25, 2010.

Accepted October 17, 2010.

${ }^{1}$ Corresponding author: uzim@volcani.agri.gov.il interactions with high urea on dairy cows' reproductive systems.

Key words: dairy heifer, dietary protein, high urea, preovulatory follicle

\section{INTRODUCTION}

Increased dietary protein was associated with detrimental effects on reproductive performance of dairy cows in several studies (Kaim at al., 1983; Ferguson et al., 1993; Rajala-Schultz et al., 2001). Excess protein, especially RDP, in ruminants' diets increases ammonia concentrations in the rumen, where it may become a nitrogen source for microbial protein. Ammonia is toxic to animal tissues and when the circulating concentration increases it is detoxified in the liver to urea, which is less toxic. Urea is a small, water-soluble molecule that permeates all cells and tissues in the body, and passes easily between blood and other tissues (Butler, 1998). In a study conducted in humans, urea concentration in follicular fluid was similar to that in plasma, and it was suggested that urea is transported by passive diffusion (Józwik et al., 2006).

The mechanism by which high dietary protein disrupts reproductive system activity in dairy cows was investigated in several studies. Threshold levels for impairment of reproductive performance were found for plasma urea nitrogen (PUN) or MUN at $19 \mathrm{mg} / \mathrm{dL}$ (Butler et al., 1996) and for PUN at $20 \mathrm{mg} / \mathrm{dL}$ (Ferguson et al., 1993). In 2 large studies, conception rates decreased with increased urea concentrations in serum (Ferguson et al., 1993) and milk (Rajala-Schultz et al., 2001). In another large study, Guo et al. (2004) found high MUN concentrations negatively affected firstservice conception rates within a herd but not between herds; they suggested that within-herd negative effects of high MUN could relate to individual cow status, whereas diet formulation appeared to have a minimal effect on fertility. In other studies, time to first ovulation, first observed estrus and first AI were not affected by high- $(20 \%)$ as compared with low- $(13 \%)$ protein diets (Carroll et al., 1988; Barton et al., 1996). Several stud- 
ies have investigated the effects of high-protein diets on follicular development, and the results have been inconsistent. Sinclair et al. (2000) did not observe differences in growth of small- and medium-sized follicles; however, the growth rate of the dominant follicle was greater in the cows fed high ammonia-generating diets. Garnsworthy et al. (2008) observed no effects of dietary protein level (range 15 to $20 \% \mathrm{CP}$ ) on development of small, medium, and dominant follicles, or on ovulation timing. Sinclair et al. (2000) reported diminished cleavage rates and blastocyst production in oocyte cultures derived from heifers fed diets high in RDP. In an in vivo study, Ocon and Hansen (2003) found a decreased proportion of oocytes becoming blastocysts following exposure to high urea concentrations during maturation, and they suggested that feeding diets rich in highly degradable $\mathrm{CP}$ compromised fertility through direct action of urea on the oocytes and through diet-induced alterations in uterine pH. Elrod and Butler (1993) found that increasing the percentage of RDP in heifers' diets from 11.3 to $18 \%$ decreased uterine $\mathrm{pH}$ during the luteal phase. In another study (Rhoads et al., 2004), intravenous infusion of urea also decreased uterine $\mathrm{pH}$, but had no effect on other measured parameters in the uterine lavage samples. Detrimental effects of high urea concentrations have been found in several functions and components of the reproductive system: follicular growth, cleavage and blastocyst formation, and the uterine environment. In light of the suggestion that carry-over effects of high urea concentrations exert the negative effects on cleavage and blastocyst formation (Jorritsma et al., 2003), we hypothesized that characteristics of preovulatory follicles surrounding the developing oocyte might be impaired and, thus, negatively affect later processes. Therefore, the objectives of the present study were to examine the effects of high-protein diets on urea infiltration into preovulatory follicles, on follicle growth, and steroid hormone concentrations.

\section{MATERIALS AND METHODS}

\section{Animals and Diets}

The Volcani Center Animal Care Committee approved all procedures involving animals in this study. Eight Israeli-Holstein heifers - 4 rumen-cannulated, and averaging $964 \pm 18 \mathrm{~d}$ of age and $632 \pm 42 \mathrm{~kg}$ in body weight; 4 intact, and averaging $644 \pm 71 \mathrm{~d}$ of age and $470 \pm 38 \mathrm{~kg}$ in body weight - were assigned to 1 of 3 treatments in a replicated $(\mathrm{n}=2) 4 \times 3$ incomplete Latin square design with 39-d periods. In each period, 1 cannulated and 1 intact heifer were assigned to 1 of 3 treatments. Heifers were housed in individual tie
Table 1. Ingredients and chemical composition of the experimental diets

\begin{tabular}{|c|c|c|c|}
\hline \multirow[b]{2}{*}{ tem } & \multicolumn{3}{|c|}{$\operatorname{Diet}^{1}$} \\
\hline & LP & MP & HP \\
\hline \multicolumn{4}{|l|}{ Ingredient, $\%$ of DM } \\
\hline Ground corn grain & 33.3 & 17.6 & 2.1 \\
\hline Soybean meal & 0.7 & 16.8 & 31.9 \\
\hline Wheat straw & 66.0 & 65.6 & 66.0 \\
\hline Vitamins and minerals ${ }^{2}$ & 0.05 & 0.05 & 0.05 \\
\hline \multicolumn{4}{|l|}{ Chemical composition } \\
\hline $\mathrm{NE}_{\mathrm{L}}, \mathrm{Mcal} / \mathrm{kg}$ & 1.27 & 1.27 & 1.27 \\
\hline $\mathrm{CP}, \%$ & 6.0 & 13.0 & 20.0 \\
\hline $\mathrm{RDP} / \mathrm{CP}, \%$ & 60.0 & 63.0 & 64.0 \\
\hline RUP/CP, $\%$ & 40.0 & 37.0 & 36.0 \\
\hline $\mathrm{NE}_{\mathrm{L}} / \mathrm{CP}, \mathrm{Mcal} / \mathrm{kg}$ & 21.2 & 9.8 & 6.7 \\
\hline $\mathrm{NE}_{\mathrm{L}} / \mathrm{RDP}, \mathrm{Mcal} / \mathrm{kg}$ & 35.3 & 15.5 & 9.9 \\
\hline $\mathrm{NDF}, \%$ & 53.5 & 54.1 & 54.6 \\
\hline
\end{tabular}

${ }^{1} \mathrm{LP}=$ low protein; $\mathrm{MP}=$ moderate protein; $\mathrm{HP}=$ high protein.

${ }^{2}$ Content per $\mathrm{kg}$ of mix: vitamin A, 12,800,000 IU; vitamin D, 2,560,000 IU; vitamin E, 16,000 mg; Mn, 64.0 g; Zn, 64.0 g; Fe, 64.0 g; Cu, 32.0 g; I, 12.8 g; Se, 0.32 g; Co, 0.48 g.

stalls at the metabolic unit of the experimental dairy farm of the Volcani Center at Bet-Dagan, Israel. Diet treatments were: 1) low protein ( $\mathbf{L P})$ - containing $6.0 \%$ of crude protein in DM; 2) moderate protein (MP) containing $13.0 \%$ of protein; and 3) high protein (HP) - containing $20.0 \%$ of protein. The diets were isoenergetic, based on approximately $66 \%$ wheat straw plus differing proportions of ground corn grain and soybean meal (Table 1$)$.

\section{Measurements and Data Collection}

Heifers were weighed before the commencement and on the last day of each period. They were individually fed daily at $0830 \mathrm{~h}$, and amounts of feed offered and refusals were recorded daily for DMI calculations; daily offers of feed were calculated to ensure $7 \%$ refusals.

Twice in each period, rumen grab samples were taken via the fistula from the ventral sac of the cannulated heifers, for determination of $\mathrm{pH}$, ammonia, and VFA. On each day, rumen samples were taken at $0800 \mathrm{~h}(0.5 \mathrm{~h}$ before feeding) and $1100 \mathrm{~h}(2.5 \mathrm{~h}$ postfeeding). Rumen $\mathrm{pH}$ was determined immediately after sampling $(\mathrm{pH}$ meter EL20; Mettler-Toledo Instruments, Shanghai, China). Rumen fluid samples were prepared by filtering through 3 layers of cotton gauze and were then divided into 2 aliquots; a 5 -mL aliquot was preserved with $5 \mathrm{~mL}$ of $10 \%$ TCA for ammonia determination, and a $10-\mathrm{mL}$ aliquot was preserved with $0.5 \mathrm{~mL}$ of mercuric chloride solution for VFA determination. The rumen fluid aliquots were shaken gently and immediately placed in storage at $-18^{\circ} \mathrm{C}$ pending analysis. 


\section{Estrus Cycle Synchronization and Follicular Fluid Aspiration}

Seven days after the start of each period, the heifers were i.m. injected with $\mathrm{PGF}_{2 \alpha}$ (2.5 mL of Estrumate; Coopers Animal Health Ltd., Berkhamsted, UK). Twelve days later, heifers' ovaries were monitored by ultrasonography with a $5-\mathrm{MHz}$ linear array transducer (Aquila; Pie Medical, Maastricht, the Netherlands) to confirm presence of a corpus luteum; after a further 1 $\mathrm{d}$ they received $2 \mathrm{i} . \mathrm{m}$. injections of $\mathrm{PGF}_{2 \alpha}, 10 \mathrm{~h}$ apart, to induce luteolysis, and $48 \mathrm{~h}$ after the first injection they were released and observed for behavioral signs of estrus. In each period, those that manifested behavioral estrus received a $\mathrm{PGF}_{2 \alpha}$ injection $14 \mathrm{~d}$ later, to induce luteolysis and to stimulate ovulation. After a further 40 $\mathrm{h}$ they were subjected to follicular fluid (FF) aspiration as follows: heifers were sedated with an i.m. injection of $0.6 \mathrm{~mL}$ of Rompun 2\% (XYL-M2 Veterinary, xylazine base $20 \mathrm{mg} / \mathrm{mL}$; VMD, Arendonk, Belgium) and were administered a local anesthetic in the form of $5 \mathrm{~mL}$ of $2 \%$ lidocaine $\mathrm{HCl}$ (Esracain 2\%, $200 \mathrm{mg} / 10 \mathrm{~mL}$; Rafa Laboratories, Jerusalem, Israel) injected epidurally between the last sacral and first caudal vertebrae. Follicles were measured and those larger than $7 \mathrm{~mm}$ were aspirated separately by means of an ultrasound scanner (Pie Medical, Maastricht, the Netherlands) connected to a $7.5-\mathrm{MHz}$ vaginal sector transducer, equipped with a needle guide and connected to a suction pump (MP86; Biometra, Goettingen, Germany) set at a flow rate of 25 to $30 \mathrm{~mL} / \mathrm{min}$. The needles used were $18 \mathrm{G}$ and were changed between follicles. After collection, $\mathrm{FF}$ was centrifuged for $15 \mathrm{~min}$, and the filtrate was separated and frozen at $-18^{\circ} \mathrm{C}$ pending analysis.

Blood samples were taken twice per week during the entire period. Additional blood samples were taken on the days of $\mathrm{PGF}_{2 \alpha}$ injections, $48 \mathrm{~h}$ later, and on the day of FF aspiration. Blood samples were collected into vacuum tubes (Becton Dickinson Systems, Cowley, UK) at $0800 \mathrm{~h}$, by coccygeal venipuncture. Plasma was separated from the samples within $10 \mathrm{~min}$ and stored at $-18^{\circ} \mathrm{C}$ for subsequent analysis.

\section{Chemical Analysis}

Diets were sampled twice per week and were dried at $70^{\circ} \mathrm{C}$ for $24 \mathrm{~h}$ (AOAC, 1990) and ground to pass through a 1.0-mm screen (Retsch S-M-100; Retsch GmbH, Haan, Germany). The ground samples were analyzed for N (AOAC, 1990; method 984.13); Ca, NDF, and ADF contents were determined with Ankom equipment (Ankom Technology, Fairport, NY), with $\alpha$-amylase and sodium sulfite used for NDF. Values of $\mathrm{NE}_{\mathrm{L}}$ for feedstuffs in the formulated diets were calculated as recommended by the National Research Council (2001). The RUP values of feedstuffs were derived according to Arieli et al. (1989).

Concentrations of NEFA in plasma and FF were determined with a NEFA C Test Kit (Wako Chemicals, Neuss, Germany). Glucose concentrations in plasma and $\mathrm{FF}$ were determined with a glucose hexokinase reagent set (Pointe Scientific, Canton, MI). The intraand interassay coefficients of variation for NEFA assays were 7.1 and $6.3 \%$, respectively, and those for glucose assays were 2.8 and $2.3 \%$, respectively. Rumen ammonia concentrations were determined with the phenol procedure (Chaney and Marbach., 1962). Concentrations of urea in plasma and FF were determined according to Coulombe and Favreau (1963).

Concentrations of progesterone $\left(\mathbf{P}_{4}\right)$ in plasma and $\mathrm{FF}$, and of estradiol $\left(\mathbf{E}_{2}\right)$ in $\mathrm{FF}$ were determined with RIA (Diagnostic Products, Los Angeles, CA), as was androstenedione $\left(\mathbf{A}_{4}\right)$ in FF (Diagnostic Systems Laboratories, Webster, TX). All FF samples were diluted 100-, 500-, or 30-fold, for $\mathrm{P}_{4}, \mathrm{E}_{2}$, and $\mathrm{A}_{4}$ assays, respectively, to match the detection range; the minimal detectable concentrations were $0.2,20.0$, and $0.1 \mathrm{ng} /$ $\mathrm{mL}$ for $\mathrm{P}_{4}, \mathrm{E}_{2}$, and $\mathrm{A}_{4}$, respectively. The intra- and interassay coefficients of variation for $\mathrm{P}_{4}$ assays were 9.1 and $8.6 \%$, respectively; those for $\mathrm{E}_{2}$ assays were 4.2 and $3.7 \%$, respectively; and those for $\mathrm{A}_{4}$ assays were 6.3 and $4.7 \%$, respectively. Follicles were regarded as $\mathrm{E}_{2}$-active when the $\mathrm{E}_{2}: \mathrm{P}_{4}$ ratio was $>1$ (Ireland and Roche, 1982), and such follicles were then subjected to further analysis.

\section{VFA Analysis}

Volatile fatty acid concentration in centrifuged ruminal fluid was assessed with a 5890 series 2 gas chromatograph (Agilent Technologies, Wilmington, DE) equipped with a capillary column $(30 \mathrm{~m} \times 0.53 \mathrm{~mm}$, $0.5 \mathrm{~mm}$; Agilent Technologies, Santa Clara, CA) and a flame ionization detector. The injection port, column, and detector were maintained at 175,130 , and $165^{\circ} \mathrm{C}$, respectively.

\section{Statistical Analysis}

Data were analyzed by the GLM procedure, version 9.1, of SAS (SAS Institute, 2002) for a $4 \times 3$ incomplete Latin square design. Intake and metabolite variables were reduced to means for each cow in each period. We have used the following model:

$$
Y_{i j k}=\mu+T_{i}+P_{j}+C_{k}\left(B_{l}\right)+B_{l}+E_{i j k},
$$

in which $Y_{i j k}=$ observation; $\mu=$ mean; $T_{i}=$ treatment effect, $i=1,2,3 ; P_{j}=$ period effect; $j=1,2,3,4$; 
Table 2. Dry matter, protein, and energy intakes, and rumen ammonia and VFA concentrations in heifers fed low (LP), moderate (MP), or high (HP) CP diets

\begin{tabular}{lcccc}
\hline & \multicolumn{3}{c}{ Treatment $^{1}$} \\
\cline { 2 - 4 } Item & LP & MP & HP & SEM \\
\hline DMI, kg/d & $8.10^{\mathrm{a}}$ & $8.90^{\mathrm{b}}$ & $8.80^{\mathrm{b}}$ & 0.08 \\
DMI/BW, $\%$ & $1.37^{\mathrm{b}}$ & $1.47^{\mathrm{a}}$ & $1.46^{\mathrm{a}}$ & 0.01 \\
CP intake, $\mathrm{kg} / \mathrm{d}$ & $0.49^{\mathrm{c}}$ & $1.15^{\mathrm{b}}$ & $1.76^{\mathrm{a}}$ & 0.01 \\
RDP intake, $\mathrm{kg} / \mathrm{d}$ & $0.29^{\mathrm{c}}$ & $0.73^{\mathrm{b}}$ & $1.13^{\mathrm{a}}$ & 0.01 \\
Energy intake, Mcal/d & $10.3^{\mathrm{b}}$ & $11.3^{\mathrm{a}}$ & $11.2^{\mathrm{a}}$ & 0.20 \\
Acetate, $\mathrm{m} M / \mathrm{dL}$ & $67.3^{\mathrm{ab}}$ & $78.1^{\mathrm{a}}$ & $65.4^{\mathrm{b}}$ & 4.0 \\
Propionate, $\mathrm{m} M / \mathrm{dL}$ & $15.0^{\mathrm{b}}$ & $20.4^{\mathrm{a}}$ & $17.0^{\mathrm{ab}}$ & 1.5 \\
Butyrate, $\mathrm{m} M / \mathrm{dL}$ & $6.8^{\mathrm{b}}$ & $9.0^{\mathrm{a}}$ & $6.8^{\mathrm{b}}$ & 0.7 \\
Valeric acid, m $M / \mathrm{dL}$ & 0.45 & 0.45 & 0.54 & 0.08 \\
Isovaleric acid, mM/dL & $0.74^{\mathrm{b}}$ & $1.33^{\mathrm{a}}$ & $1.23^{\mathrm{a}}$ & 0.13 \\
Caproic acid, $\mathrm{m} M / \mathrm{dL}$ & 0.15 & 0.17 & 0.10 & 0.04 \\
Acetate/propionate & 4.6 & 3.9 & 4.4 & 0.3 \\
Total VFA, $\mathrm{m} M / \mathrm{dL}$ & $89.9^{\mathrm{b}}$ & $108.3^{\mathrm{a}}$ & $90.6^{\mathrm{b}}$ & 6.0 \\
Ammonia, $\mathrm{mg} / \mathrm{dL}$ & $3.4^{\mathrm{c}}$ & $13.3^{\mathrm{b}}$ & $22.4^{\mathrm{a}}$ & 1.3 \\
Rumen $\mathrm{pH}$ & 6.68 & 6.71 & 6.77 & 0.06 \\
\hline
\end{tabular}

${ }^{a-c}$ Means in the same row without a common superscript differ $(P<0.05)$.

${ }^{1}$ Eight heifers, 4 fitted with rumen fistula and 4 intact, were assigned to each of 3 treatments in a $4 \times 3$ incomplete Latin square design and fed diets containing 6.0\% (LP), $13.0 \%$ (MP), or $20.1 \%$ (HP) CP.

$C_{k}\left(B_{l}\right)=$ cow effect; $k=1, \ldots, 8$, nested within block $l$ (1 block for cannulated heifers and 1 block for intact heifers); $B_{l}=$ block effect, $l=1,2$; and $E_{i j k}=$ residual error.

Means were separated by using the LSMEANS statement option with adjustment for multiple comparisons by the Tukey method $(P=0.05)$. Least squares means and adjusted standard error of the means are presented in Tables 2 to 4 and $P<0.05$ was accepted as significant unless otherwise stated.

\section{RESULTS AND DISCUSSION}

\section{Dry Matter Intake, Rumen Ammonia, and PUN Concentrations}

Dry matter intake was $9 \%$ lower under the LP diet than that under the MP and HP $\operatorname{diets}(P<0.05$; Table 2 ), and also was lower when expressed as a percentage of BW $(P<0.05$; Table 2$)$. The lowered intake in LP probably reflected decreased microbial metabolism and longer ruminal retention time. Several studies reported decreases in DMI with decreasing CP content of diet. Ipharraguerre and Clark (2005) observed lower DMI in cows fed diets containing $14.8 \%$ of $\mathrm{CP}$ than in those fed with 16.8 or $18.7 \%$ CP. Similar decreases in DMI were reported when the $\mathrm{CP}$ content of dairy cow diet was decreased from 18 to $15 \%$ (Weigel et al., 1997) or from 18.4 to $15.1 \%$ (Broderick, 2003). In another study, decreasing the CP content from 19.3 to $15.4 \%$ during wk 1 to 16 of lactation did not affect DMI (Wu and Satter, 2000). Moreover, in a similar study to the present one, with nonlactating cows, decreasing the $\mathrm{CP}$ content from 27.4 to $12.0 \%$ did not affect DMI (GarciaBojalil et al., 1994). The inconsistency among findings might be related to differences in degradable protein to energy ratio and in stage of lactation.

In the present study, total VFA concentration was $20 \%$ higher under the MP diet than under each of the other diets $(P<0.002$; Table 2$)$. Acetate concentration in the rumen was higher under the MP than under the HP diet $(P<0.03)$, whereas propionate and butyrate concentrations were higher under the MP diet than under the LP diet $(P<0.04$; Table 2$)$. Acetate to propionate ratios were $4.6,3.8$, and 4.4 under the LP, $\mathrm{MP}$, and HP diet, respectively, in accordance with the corresponding energy intakes in these diets.

Rumen ammonia and PUN concentrations gradually increased as dietary $\mathrm{CP}$ content increased (Tables 2 and 3). Under the LP diet, rumen $\mathrm{N}$-ammonia content was lower than the minimal level of $5 \mathrm{mg} / \mathrm{dL}$ needed for

Table 3. Plasma urea nitrogen (PUN), NEFA, and glucose concentrations in heifers fed low- (LP), moderate- (MP), and high(HP) protein diets

\begin{tabular}{lrcrc}
\hline & \multicolumn{3}{c}{ Treatment $^{1}$} \\
\cline { 2 - 4 } Item & \multicolumn{1}{c}{ LP } & MP & HP & SEM \\
\hline PUN, mg/dL & $5.6^{\mathrm{c}}$ & $14.5^{\mathrm{b}}$ & $23.1^{\mathrm{a}}$ & 1.0 \\
NEFA, $\mu \mathrm{Eq} / \mathrm{L}$ & 133.9 & 136.9 & 142.8 & 7.6 \\
Glucose, $\mathrm{mg} / \mathrm{dL}$ & 74.9 & 70.8 & 78.6 & 3.3 \\
\hline
\end{tabular}

${ }^{\mathrm{a}-\mathrm{c}}$ Means in the same row without a common superscript differ $(P<$ $0.05)$.

${ }^{1}$ Eight heifers, 4 fitted with rumen fistula and 4 intact, were assigned to each of 3 treatments in a $4 \times 3$ incomplete Latin square design and fed diets containing $6.0 \%$ (LP), $13.0 \%$ (MP), or $20.1 \%$ (HP) CP. 
Table 4. Concentrations of progesterone $\left(\mathrm{P}_{4}\right)$ in plasma at time of $\mathrm{PGF}_{2 \alpha}$ injection, and of metabolites and hormones in follicular fluid

\begin{tabular}{lcccc}
\hline & \multicolumn{3}{c}{ Treatment $^{1}$} \\
\cline { 2 - 3 } Item & LP & MP & HP & SEM \\
\hline Plasma $\mathrm{P}_{4}$ at d 13 of cycle, $\mathrm{ng} / \mathrm{mL}$ & 5.33 & 4.99 & 5.44 & 0.31 \\
Follicles, $\mathrm{n}$ & 12 & 10 & 8 & \\
Diameter, $\mathrm{mm}$ & 11.8 & 12.1 & 12.3 & 0.9 \\
Urea nitrogen, $\mathrm{mg} / \mathrm{dL}$ & $6.8^{\mathrm{c}}$ & $14.5^{\mathrm{b}}$ & $21.5^{\mathrm{a}}$ & 0.6 \\
NEFA, $\mu \mathrm{Eq} / \mathrm{L}$ & 241.6 & 197.0 & 215.8 & 47.0 \\
Glucose, $\mathrm{mg} / \mathrm{dL}$ & 67.6 & 74.5 & 66.8 & 4.6 \\
$\mathrm{P}_{4}, \mathrm{ng} / \mathrm{mL}$ & $109.4^{\mathrm{b}}$ & $115.6^{\mathrm{b}}$ & $159.6^{\mathrm{a}}$ & 21.0 \\
Estradiol $\left(\mathrm{E}_{2}\right), \mathrm{ng} / \mathrm{mL}$ & $915.7^{\mathrm{ab}}$ & $586.2^{\mathrm{b}}$ & $1,462.1^{\mathrm{a}}$ & 260.0 \\
$\mathrm{E}_{2} / \mathrm{P}_{4}$ & 13.4 & 7.7 & 12.6 & 2.5 \\
Androstenedione, $\mathrm{ng} / \mathrm{mL}$ & 47.1 & 35.1 & 11.9 & 20.0 \\
\hline
\end{tabular}

${ }^{\mathrm{a}-\mathrm{c}}$ Means in the same row without a common superscript differ $(P<0.05)$.

${ }^{1} \mathrm{LP}=$ low-protein diet; $\mathrm{MP}=$ moderate-protein diet; HP $=$ high-protein diet; 8 heifers, 4 fitted with rumen fistula and 4 intact, were assigned to each of 3 treatments in a $4 \times 3$ incomplete Latin square design and fed diets containing $6.0 \%(\mathrm{LP}), 13.0 \%(\mathrm{MP})$, or $20.1 \%$ (HP) CP.

microbial protein synthesis (Satter and Slyter, 1974), whereas under the HP diet it was 6.6 and 1.7 times higher, respectively, than under the LP and MP diets $(P<0.002)$. Under the HP diet, intake of RDP $(1.13$ $\mathrm{kg} / \mathrm{d}$ ) was 3.9 times higher than under the LP diet $(0.29 \mathrm{~kg} / \mathrm{d})$, and RDP intake under the MP diet lay between these, at $0.73 \mathrm{~kg} / \mathrm{d}$. Degradable protein provides a source of ammonia for microbial protein synthesis, which depends on ruminal availability of carbohydrates as an energy source for microbial growth. In the present study, the $\mathrm{NE}_{\mathrm{L}}$ per RDP consumed was 35.4, 15.6, and $9.9 \mathrm{Mcal} / \mathrm{kg}$ under the LP, MP, and HP diet, respectively $(P<0.002)$. The high rumen ammonia concentrations in the HP-fed animals underline the importance of the ratio between degradable energy sources and protein in the rumen in decreasing ammonia concentrations, as also reported elsewhere (Hoover and Stokes, 1991; Shabi et al., 1998).

Part of the ammonia generated by protein degradation in the rumen exits the rumen and is converted to urea - a nontoxic nitrogen form - in the liver. Thus, Gustafsson and Palmquist (1993) found that the rumen ammonia peak was followed after 1.5 to $2.0 \mathrm{~h}$ by a PUN peak. In the present study, a similar pattern was observed for rumen ammonia and PUN concentrations, with concentrations increasing gradually as diet protein content increased: PUN concentrations were 3.7 and 1.4 times higher under the HP diet than under LP and MP diets, respectively $(P<0.001)$. These results are consistent with those of Ferguson et al. (1993), who found that increasing dietary CP from 12.2 to $17.6 \%$ increased PUN concentrations from 8.2 to $20.7 \mathrm{mg} / \mathrm{dL}$, and also with those of Howard et al. (1987). No differences were observed between diets in concentrations of NEFA and glucose in plasma (Table 3 ).

\section{Urea and Hormone Concentrations in Preovulatory Follicular Fluid}

Totals of 17, 18, and 12 follicles larger than $7 \mathrm{~mm}$ were aspirated under the LP, MP, and HP diets, respectively. Among them 12, 10, and 8 follicles, under the LP, MP, and $\mathrm{HP}$ diets, respectively, were regarded as $\mathrm{E}_{2}$-active and were subjected to further analysis. In 2 cases (1 heifer under the HP diet and 1 under the MP diet), large follicles were not aspirated because of technical problems, and no $\mathrm{E}_{2}$-active follicles were detected.

Urea-nitrogen concentrations in preovulatory FF were very similar to PUN concentrations (Figure 1). Urea nitrogen concentrations in $\mathrm{FF}$ were highest under the $\mathrm{HP}$ diet $(21.5 \mathrm{mg} / \mathrm{dL})$, intermediate under the MP diet $(14.5 \mathrm{mg} / \mathrm{dL})$, and lowest under the LP diet $(6.8 \mathrm{mg} /$ $\mathrm{dL}$ ). Urea is a small, water-soluble molecule that passes easily between blood and other tissues, including the ovary (Gustafsson and Palmquist, 1993; Butler, 1998). The similarity between urea concentrations in plasma and FF supports the premise that urea infiltrates into ovary components, including FF of preovulatory follicles. Similar to those of urea, glucose concentrations in FF were very similar to those in blood, and were unaffected by the experimental diets. No between-diets differences were observed in NEFA concentrations in plasma and FF; however, whereas concentrations of urea and glucose in plasma were similar to those in FF, the NEFA concentrations in FF were 1.8 times higher than those in plasma. Furthermore, the correlation between NEFA concentrations in plasma and in FF was low and not significant $(P<0.85)$. Differences between NEFA concentrations in $\mathrm{FF}$ and in plasma were also observed by Yao et al. (1980) in small ovarian follicles in swine. The NEFA molecules are bound to albumin, and higher 


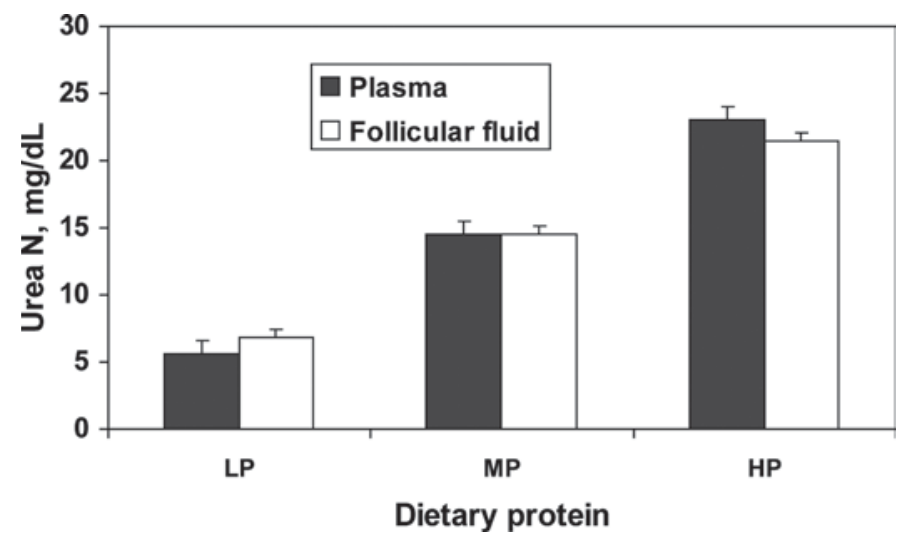

Figure 1. Urea nitrogen concentration in plasma $(\boldsymbol{\square})$ and follicular fluid $(\square)$ aspirated from preovulatory follicles in heifers fed diets containing $6.0 \%$ (low protein; LP), $13.0 \%$ (moderate protein; MP), or $20.1 \%$ (high protein; HP) CP.

levels of albumin were found in $\mathrm{FF}$ than in plasma, which might partly explain the gradient in NEFA concentrations found by Yao et al. (1980) between plasma and FF. The higher NEFA concentrations in FF than in plasma found in the present study contrasted with the findings of Comin et al. (2002) and of Leroy et al. (2005), who reported lower NEFA concentrations in FF than in plasma, but the present findings partly agree with those of Yao et al. (1980). However, Leroy et al. (2005) took measurements early postpartum, in unsynchronized estrous cycles and, moreover, they found that at 44 DIM, NEFA concentrations did not differ between plasma and FF.

Several studies found decreases in reproductive performance when PUN concentrations exceeded $19 \mathrm{mg} /$ dL (Butler et al., 1996; Garcia-Bojalil et al., 1998; McCormick et al., 1999), but others did not (Howard et al., 1987; Garcia-Bojalil et al., 1994). In the present study, the HP diet increased the PUN concentrations to 23.1 $\mathrm{mg} / \mathrm{dL}$, which is considered within the sensitive range. In a study of nonlactating cows by Garcia-Bojalil et al. (1994), increasing the dietary CP from 12.7 to $27.4 \%$ increased the PUN concentration from 9.8 to $21.3 \mathrm{mg} /$ $\mathrm{dL}$, with no effect on preovulatory follicle size or on other parameters that evaluated follicular development, such as percentage of preovulatory, anovulatory, and ovulatory follicles. In another study Sinclair et al. (2000) found that a high ammonia-generating diet increased dominant follicle growth rate, and at ovulation the dominant follicle diameter was greater than that in heifers fed a low ammonia-generating diet. In the present study, the diameter of preovulatory follicles aspirated $40 \mathrm{~h}$ after $\mathrm{PGF}_{2 \alpha}$ injection averaged $12.1 \mathrm{~mm}$, and was not affected by dietary protein content; this is consistent with findings of Garcia-Bojalil et al. (1994), but not with those of Sinclair et al. (2000). Moreover, in the present study, across-treatment analysis showed positive correlation between FF urea concentration and preovulatory follicle diameter $(\mathrm{r}=0.46 ; P<0.03)$, which supports the findings of Sinclair et al. (2000).

To the best of our knowledge, the present study is the first to examine the effect of high dietary $\mathrm{CP}$ on steroid concentrations in in vivo-aspirated preovulatory follicles. Concentrations of $\mathrm{E}_{2}$ in $\mathrm{FF}$ were 2.2 times as great under the HP diet as under the MP $\operatorname{diet}(P<$ $0.03)$, and tended $(P<0.07)$ to be higher under the LP diet than under the MP diet (Table 4). In another study, no differences were observed between $\mathrm{E}_{2}$ concentrations in small- and medium-size follicles obtained from heifers fed a high ammonia-generating diet and in those from animals fed a low ammonia-generating diet (Sinclair et al., 2000). Garnsworthy et al. (2008) found that plasma concentrations of $\mathrm{E}_{2}$ were not affected by dietary metabolizable crude protein. Moreover, in the present study, across-treatment analysis revealed a positive correlation between PUN and $\mathrm{E}_{2}$ concentrations in FF $(\mathrm{r}=0.68 ; P<0.02)$, but not between $\mathrm{E}_{2}$ and urea nitrogen concentrations in FF. We do not have a putative explanation for the differences between PUN and urea nitrogen concentrations in FF and their relationship with $\mathrm{E}_{2}$ concentrations in FF.

Similar to those of $\mathrm{E}_{2}, \mathrm{FF}$ concentrations of $\mathrm{P}_{4}$ were higher under the HP diet than under either of the other diets, which is in accordance with Sinclair et al. (2000), who found higher $\mathrm{P}_{4}$ concentrations in small- and medium-size follicles obtained from heifers fed a high ammonia-generating diet than in those from animals fed a low ammonia-generating diet. In the present study, no between-groups differences in plasma $\mathrm{P}_{4}$ concentrations were observed at the times of $\mathrm{PGF}_{2 \alpha}$ injection and follicle aspiration. However, Sinclair et al. (2000) observed higher plasma $\mathrm{P}_{4}$ concentrations during the luteal phase of the estrous cycles in heifers fed a high ammonia-generating diet than in those fed a low ammonia-generating one. In contrast, Jordan and Swanson (1979) reported lower $\mathrm{P}_{4}$ concentrations in plasma at d 14 of the estrus cycle of early postpartum cows fed 16.3 and $19.3 \% \mathrm{CP}$ than in those fed $12.7 \%$ CP. Similar to our present findings, Barton et al. (1996) found no difference in plasma $\mathrm{P}_{4}$ concentrations between cows fed 20 or $13 \%$ CP, and Elrod and Butler (1993) found no such difference between heifers fed diets high or low in degradable protein. The discrepancies between studies might be related to stage of lactation and the interaction between energy balance and CP, as previously suggested by Butler (1998).

In the present study, synthesis of $\mathrm{E}_{2}$ and $\mathrm{P}_{4}$ in the preovulatory $\mathrm{FF}$ was not impaired by high urea concentration in plasma and $\mathrm{FF}$, and, moreover, the $\mathrm{E}_{2}$ 
to $\mathrm{P}_{4}$ ratio, which is a recognized parameter for indicating follicle quality and vitality, did not differ between dietary treatments. Although several studies reported lower reproductive performance in dairy cows fed high-protein diets, the mechanism is not clear. The reproductive system could be impaired by high PUN at several stages: preantral and antral folliculogenesis, preovulatory follicle development and steroidogenesis, ovulation and fertilization, as well as by the intrauterine environment. Indeed, high PUN elicited negative effects on in vitro fertilization (Sinclair et al., 2000) and on the intrauterine environment (Elrod and Butler, 1993), but not on folliculogenesis (Garnsworthy et al., 2008). The inconsistency of findings regarding effects of high-CP diets on cows' reproductive systems indicates that effects of high urea might involve other physiological and metabolic factors. In the present study, we have used nonlactating heifers in investigating the effects of high-CP diets on preovulatory follicles. As suggested by Garcia-Bojalil et al. (1994), use of nonlactating heifers eliminates other potentially interacting factors, such as negative energy balance, changes in DMI, and health problems. Nevertheless, detrimental effects of high PUN on the reproductive system might be exacerbated by activities of other physiological, nutritional, and metabolic factors (Garcia-Bojalil et al., 1994; Butler, 1998). The present finding that high-CP diets did not impair preovulatory characteristics might indicate absence of such interactions in nonlactating heifers, in contrast to their presence in lactating cows. Moreover, it also might be concluded that the detrimental effects of high PUN are manifested in other components of the reproductive system, rather than in preovulatory follicles.

In conclusion, feeding a high-protein diet to dairy heifers increased PUN concentrations and, in a very similar manner, the urea nitrogen concentrations in preovulatory FF. However, although urea infiltrated into the $\mathrm{FF}$, no impairment was observed in steroid hormone synthesis or in other characteristics of preovulatory follicles. The nonobservation of detrimental effects of high urea in the present study might be related to the use of nonlactating heifers, which avoids interactions with other parameters. Alternatively, it might be that the detrimental effect of high urea applies to other aspects of the reproductive system, rather than to folliculogenesis or functionality of preovulatory follicles.

\section{ACKNOWLEDGMENTS}

This research was partially supported by the Israeli Cattle Breeders' Association. We thank the crew of the Metabolic Unit of the experimental dairy farm at the Volcani Center (Bet Dagan, Israel) for their assistance with animal care.

\section{REFERENCES}

Arieli, A., I. Bruckental, and E. Smoler. 1989. Prediction of duodenal nitrogen supply from degradation or organic and nitrogenous matter in situ. J. Dairy Sci. 72:2532-2539.

Association of Official Analytical Chemists (AOAC). 1990. Official Methods of Analysis, 14th ed. AOAC, Arlington, VA. 80-88.

Barton, B. A., H. A. Rosario, G. W. Anderson, B. P. Grindle, and D. J. Carroll. 1996. Effects of dietary crude protein, breed, parity, and health status on the fertility of dairy cows. J. Dairy Sci. 79:2225-2236.

Broderick, G. A. 2003. Effects of varying dietary protein and energy levels on the production of lactating dairy cows. J. Dairy Sci. 86:1370-1381.

Butler, W. R. 1998. Review: Effect of protein nutrition on ovarian and uterine physiology in dairy cattle. J. Dairy Sci. 81:2533-2539.

Butler, W. R., J. J. Calaman, and S. W. Beam. 1996. Plasma and milk urea nitrogen in relation to pregnancy rate in lactating dairy cattle. J. Anim. Sci. 74:858-865.

Carroll, D. J., B. A. Barton, G. W. Anderson, and R. D. Smith. 1988. Influence of protein intake and feeding strategy on reproductive performance of dairy cows. J. Dairy Sci. 71:3470-3481.

Chaney, A. L., and E. P. Marbach. 1962. Modified reagents for determination of urea and ammonia. Clin. Chem. 8:130-132.

Comin, A., D. Gerin, A. Cappa, V. Marchi, R. Renaville, M. Motta, U. Fazzini, and A. Prandi. 2002. The effects of an acute energy deficit on the hormone profile of dominant follicles in dairy cows. Theriogenology 58:899-910.

Coulombe, J. J., and L. Favreau. 1963. A new simple semimicro method for colorimetric determination of urea. Clin. Chem. 9:102-108.

Elrod, C. C., and W. R. Butler. 1993. Reduction of fertility and alteration of uterine $\mathrm{pH}$ in heifers fed excess ruminally degradable protein. J. Anim. Sci. 71:694-701.

Ferguson, J. D., D. T. Galligan, T. Blanchard, and M. Reeves. 1993. Serum urea nitrogen and conception rate: The usefulness of test information. J. Dairy Sci. 76:3742-3746.

Garcia-Bojalil, C. M., C. R. Staples, C. A. Risco, J. D. Savio, and W. W. Thatcher. 1998. Protein degradability and calcium salts of long-chain fatty acids in the diets of lactating dairy cows: Reproductive responses. J. Dairy Sci. 81:1385-1395.

Garcia-Bojalil, C. M., C. R. Staples, W. W. Thatcher, and M. Drost. 1994. Protein intake and development of ovarian follicles and embryos of superovulated nonlactating dairy cows. J. Dairy Sci. $77: 2537-2548$.

Garnsworthy, P. C., J. G. Gong, D. G. Armstrong, J. R. Newbold, M. Marsden, S. E. Richards, G. E. Mann, K. D. Sinclair, and R. Webb. 2008. Nutrition, metabolism, and fertility in dairy cows: 3 . Amino acids and ovarian function. J. Dairy Sci. 91:4190-4197.

Guo, K., E. Russek-Cohen, M. A. Varner, and R. A. Kohn. 2004 Effects of milk urea nitrogen and other factors on probability of conception of dairy cows. J. Dairy Sci. 87:1878-1885.

Gustafsson, A. H., and D. L. Palmquist. 1993. Diurnal variation of rumen ammonia, serum urea, and milk urea in dairy cows at high and low yields. J. Dairy Sci. 76:475-484.

Hoover, W. H., and S. R. Stokes. 1991. Balancing carbohydrates and proteins for optimum rumen microbial yield. J. Dairy Sci. 74:3630-3644.

Howard, H. J., E. P. Aalseth, G. D. Adams, L. J. Bush, R. W. McNew, and L. J. Dawson. 1987. Influence of dietary protein on reproductive performance of dairy cows. J. Dairy Sci. 70:1563-1571.

Ipharraguerre, I. R., and J. H. Clark. 2005. Varying protein and starch in the diet of dairy cows. II. Effects on performance and nitrogen utilization for milk production. J. Dairy Sci. 88:2556-2570.

Ireland, J. J., and F. Roche. 1982. Development of antral follicles in cattle after prostaglandin-induced luteolysis: Changes in serum hormones, steroids in follicles fluids and gonadotropin receptors. Endocrinology 111:2077-2086.

Jordan, E. R., and L. V. Swanson. 1979. Serum progesterone and luteinizing hormone in dairy cattle fed varying levels of crude protein. J. Anim. Sci. 48:1154-1158. 
Jorritsma, R., T. Wensing, T. A. M. Kruip, P. L. A. M. Vos, and J. P. T. M. Noordhuizen. 2003. Metabolic changes in early lactation and impaired reproductive performance in dairy cows. Vet. Res. $34: 11-26$.

Józwik, M., M. Józwik, C. Teng, and F. C. Battaglia. 2006. Amino acid, ammonia and urea concentrations in human pre-ovulatory ovarian follicular fluid. Hum. Reprod. 21:2776-2782.

Kaim, M., Y. Folman, H. Neumark, and W. Kaufmann. 1983. The effect of protein intake and lactation number on postpartum body weight loss and reproductive performance of dairy cows. Anim. Prod. 37:229-235.

Leroy, J. L. M. R., T. Vanholder, B. Mateusen, A. Christophe, G. Opsomer, A. de Kruif, G. Genicot, and A. Van Soom. 2005. Nonesterified fatty acids in follicular fluid of dairy cows and their effect on developmental capacity of bovine oocytes in vitro. Reproduction 130:485-495.

McCormick, M. E., D. D. French, T. F. Brown, G. J. Cuomo, A. M. Chapa, J. M. Fernandez, J. F. Beatty, and D. C. Blouin. 1999. Crude protein and rumen undegradable protein effects on reproduction and lactation performance of Holstein cows. J. Dairy Sci. 82:2697-2708

National Research Council. 2001. Nutrient Requirements of Dairy Cattle. 7th rev. ed. Natl. Acad. Sci., Washington, DC.

Ocon, O. M., and P. J. Hansen. 2003. Disruption of bovine oocytes and preimplantation embryos by urea and acidic pH. J. Dairy Sci. 86:1194-1200.

Rajala-Schultz, P. J., W. J. A. Saville, G. S. Frazer, and T. E. Wittum. 2001. Association between milk urea nitrogen and fertility in Ohio dairy cows. J. Dairy Sci. 84:482-489.
Rhoads, M. L., R. O. Gilbert, M. C. Lucy, and W. R. Butler. 2004. Effects of urea infusion on the uterine luminal environment of dairy cows. J. Dairy Sci. 87:2896-2901.

SAS Institute. 2002. SAS User's Guide: Statistics. Version 9.2. SAS Inst., Inc., Cary, NC.

Satter, L. D., and L. L. Slyter. 1974. Effect of ammonia concentration on rumen microbial protein production in vitro. Br. J. Nutr. 32:199-208.

Shabi, Z., A. Arieli, I. Bruckental, Y. Aharoni, S. Zamwel, A. Bor, and H. Tagari. 1998. Effect of the synchronization of the degradation of dietary crude protein and organic matter and feeding frequency on ruminal fermentation and flow of digesta in the abomasum of dairy cows. J. Dairy Sci. 81:1991-2000.

Sinclair, K. D., M. Kuran, F. E. Gebbie, R. Webb, and T. G. McEvoy 2000. Nitrogen metabolism and fertility in cattle: II. Development of oocytes recovered from heifers offered diets differing in their rate of nitrogen release in the rumen. J. Anim. Sci. 78:2670-2680.

Weigel, D. J., J. P. Elliott, and J. H. Clark. 1997. Effects of amount and ruminal degradability of protein on nutrient digestibility and production by cows fed tallow. J. Dairy Sci. 80:1150-1159.

Wu, Z., and L. D. Satter. 2000. Milk production during the complete lactation of dairy cows fed diets containing different amounts of protein. J. Dairy Sci. 83:1042-1051.

Yao, J. K., R. J. Ryan, and P. J. Dyck. 1980. The porcine ovarian follicle. VI. Comparison of fatty acid composition of serum and follicular fluid at different developmental stages. Biol. Reprod. $22: 141-147$. 